\title{
Cultural Heritage: An Urban Memoir Towards Idanre City Prosperity
}

\author{
Oluwasegun ESAN, Department of Architecture, Faculty of Environmental Sciences, \\ University of Lagos, Akoka, Lagos, Nigeria
}

\begin{abstract}
The present tasks facing most of the cities in Nigeria is over reliance on crude oil. The task ahead is to ensure cities function properly and cater for its inhabitants adequately. Several efforts to diversify and develop other sectors of the economy over the last two decades yielded little result. The crash in global crude oil economy is compelling Nigerian cities to explore alternative source of income. At this crucial time, a closer look at creative industry to leverage on heritage resources is being explored. The paper examines precious Idanre heritage as a developmental tool towards urban prosperity. Idanre is a relatively small and historic town in Ondo State situated at the foot of scenic Idanre hills with unique cultural heritage and propensity to attract diverse tourist locally and internationally. The study adopts qualitative research approach through purposive interview and focus group discussion. Community participation will permit inclusive planning for the city. This research findings include 1350AD ancient palace on the hill: unique Orogho, Usalu and Udale quarters; Orosun Sacred Groove and Festival; Agaga Hills; Idanre Forest Reserve; and small-scale Cocoa Agricultural Estates. Community consensus identified heritage memorabilia, cottage industry, small scale local chocolate industry, community sacred forest tour guides and Orosun festival as to enhance the prosperity of the town. Conclusively, community opinion, cultural custodians, traditional rulers, heritage tourists were various elements of Idanre city system as Idanre city is tied to its heritage resources. The legibility of Idanre city is influenced by heritage resources as the collective memory that can be translated into urban prosperity. This paper recommends that innovation capacity and citizenry interaction are fundamental for desired Idanre prosperity through a robust heritage resource deeply rooted in creative industry rooted in heritage resources. Government need to promote the development of cultural heritage and creative industries. Furthermore, urban planning policies should be in favour of mixed-use, well defined and connected spatial clusters within the urban network. An integrated and comprehensive strategy is also needed for the development of creative industries.
\end{abstract}

\section{Keywords}

Creative Industry, Cultural Heritage, Memorabilia, Memory, Urban Prosperity

\section{Introduction}

Urban memoir is regarded as an expression of collective memory that has been shaped within a particular space over a period time. Urban memoir is an important aspect of the cultural heritage of a city to be captured, preserved and branded for future generations (Jennifer \& Martin , 2018). This study considered urban memoir and how it can be used for city prosperity such as the case of Idanre city. The proposition is to conceptualize Idanre city as a cultural environment where cultural heritage is both preserved and branded towards urban prosperity. Heritage bequests are facing intensive pressures mainly due to swift urbanization driven by colossal population growth rate and rural migrants' influx (Andres, 20111). Global population upsurge, massive migration, quest for urban infrastructural 
improvement and revitalization of decayed inner core area underpin the loss of heritage resources in recent years (Elseragy, Elnokaly, \& Sabbagh, 2017). The fact remains that preserved heritage enhance people's lives, offering a deep and inspirational sense of connection to the city and the landscape (Shahrul, Hasnizan, \& Elma, 2013). Historic towns and cultural landscapes are considered unique resources for the preservation of cities identity and historic characters (Antonio, 2013). This is in spite of transformation enhanced by globalization, rapid urbanization and the quest for advanced production technology in developing nations (Somekh, Correa, \& Mauro, 2017).

As noted by Fajemirokun (2004), Sixty-four sites in Nigeria have been declared by the Federal Government of Nigeria to be historic landscape for preservation. Recent research has found that several of the historic sites no longer exist. Typical examples: Hebe Mosque, Bebeji, Kano State that was 300 years old when it was listed in 1951. Unfortunately, it has now totally collapsed (Fajemirokun, 2004). Interestingly, the Federal Government of Nigeria has identified tourism, especially heritage tourism as alternative foreign exchange earning to the mono-cultural crude oil economy. This will encourage urban prosperity. Concern for urban prosperity in Nigeria came to the forefront in 2016 when global hydrocarbon industries collapsed leading to low investment in urban infrastructure. Adejumo \& Esan (2020) posited that with the exception of metropolitan Lagos, most Nigerian cities are not financially viable. Nigeria cities grew on crude oil enterprises in faraway Niger Delta Arcuate coastal landscapes. Alternative viable urban economic resources in the mode of heritage capita, is required to trigger urban prosperity. This is true of Idanre city, a historic town in the western part of Nigeria. Recent studies pointed to heritage resources as the socio-cultural capita that enhanced the prosperity of city heritage tourism (UNESCO-ICOMOS, 2019). The paper examines precious Idanre heritage as a developmental tool towards urban prosperity.

\subsection{Study Area}

Idanre is about $20 \mathrm{~km}$ (12 mi) southeast of the state's capital and its geographical coordinates are $6^{\circ} 43^{\prime}$ $0 "$ North, $5^{\circ} 6^{\prime} 0^{\prime \prime}$ East. The town is a cluster of hilly settlement. The hills surround the town, envelope it and dominate life in the town. One sees the hills and virtually every activity revolves round this collection of hills. Apart from that cultural role, the town pulls the wealthy and the commoner, basically due to its perceived mystical aura and the giddy excitement lovers of nature get when they surmount the steep, terrain to witness spectacular view of the new town and adjoining hills in a breath-taking manner (Adeleye \& Folarin, 2014). Idanre City is one of the most awesome and beautiful natural landscapes in Ondo State and Nigeria. Added to its beauty which fires human curiosity is the fact that the entire people of Idanre lived on these boulders for almost a millennium. Ondo State no doubt is one of the richly endowed states in the south-western end of the country of its many tourism assets, Idanre hills in Idanre town is perhaps the most popular and captivating. Idanre hill consists of high plains with spectacular valleys interspersed with inselbergs of about 3,000 feet above sea level. Some of cultural relics include Owa's Palace, shrines, old Court, Belfry, Agbooogun's footprint, thunder water (Omi Aopara) and burial mounds and grounds. It also has diverse eco-systems of flora and fauna. Oke Idanre contains very important bio-physical whose interaction with the physical features created an enduring cultural landscape within the setting (Akintan, 2008). The study adopts qualitative research approach using purposive interview and focus group discussion. Community participation will permit inclusive planning for the city.

\section{Literature Review}

Shahrul et al. (2013) believed heritage significance enrich people's lives, offering a deep and inspirational sense of connection to the city and landscape. Historic towns and cultural landscape have formed our societies and are considered irreplaceable assets for the present and future generations in other to preserve the cultural identity and historic characters of such towns in the light of the transformation brought by the forces of globalization and urbanization as well as progress in production technology (Scott, 2006). Intangible cultural heritage is commonly defined as not having a physical presence 
(Pietrobruno, 2009). Letícia (2011) noted the processes and actions of colonization have resulted in disruptions to the referencing, practice, transmission and provenance of tangible and intangible indigenous cultural heritage (Espinoza, 2015). Similarly, Indigenous people's intangible cultural heritage has often been poorly understood or disregarded as "too difficult" to properly acknowledge or record in terms of its context, purpose or the persons or places from where it first became known (Antia, 2005).

Cultural heritage at some point connect with the memory of the people, objects valued for their connection with historical events, festivals or entertainment such as posters, crafts, arts, publicity photographs as well as any other memorabilia form source of revenue for such city prosperity (Flew, 2011). It is no gain saying that tourism is a rapidly growing phenomenon and has become one of the largest industries in the world. The impact of tourism is extremely varied. On one hand, it plays an important and certainly positive role in the socio-economic and political development in destination countries by, for instance, offering new employment opportunities (Eneji, Odey, \& Bullus, 2016). Also, in certain instances, it may contribute to a broader cultural understanding by creating awareness, respecting the diversity of cultures and ways of life. On the other hand, cultural heritage is regarded as a tool to create jobs (Yusuff \& Akinde, 2015). Mark \& Susan (2008) noted that the creative industries represent the latest wave of interest in culture as a post-industrial urban revitalization strategy. The creative industry has a wider set of industries in which "creativity" is viewed as an asset that can spur productivity (Comunian, 2011). Therefore, a city prosperity based creative economy is an ecosystem approached to culture-based city revitalization that integrates city residence with the regional economy and the civil society at large bringing about city self-sufficiency. The paper explores Idanre tangible heritage on the much-needed memorabilia to trigger urban prosperity.

\section{Results/Findings/Discussion}

This research findings include 1350AD ancient palace on the hill: unique Orogho, Usalu and Udale quarters (Administrative Quarters); Orosun Sacred Groove and Festival; Agaga Hills; Idanre Forest Reserve; Small-scale Cocoa Agricultural Estates. Community consensus identified heritage memorabilia, cottage industry, small scale local chocolate industry, community sacred forest tour guides and Orosun festival as creative industry to enhance the prosperity of the town.

\subsection{The Ancient Palace}

The pattern of settlement in the study area is basically clustered inwardly and it is partly linear along the access road. Houses are pocketed at various location to one another at the hill top and in between hill range giving the city unique scenic view which were closely knitted with various shapes and sizes. Split of houses is also located along the access road. As a natural and cultural landscape, The Idanre Hills had been a home for the Idanre community for almost a millennium. It is a cluster of intimidating and imposing hills housing some wonderful things which confound the senses. The hills surround the town, envelope it and dominate life in the town by cultural relics include Owa's Palace, shrines, old Court, Belfry, Agboogun's footprint, thunder water (Omi Aopara) and burial mounds and grounds. 


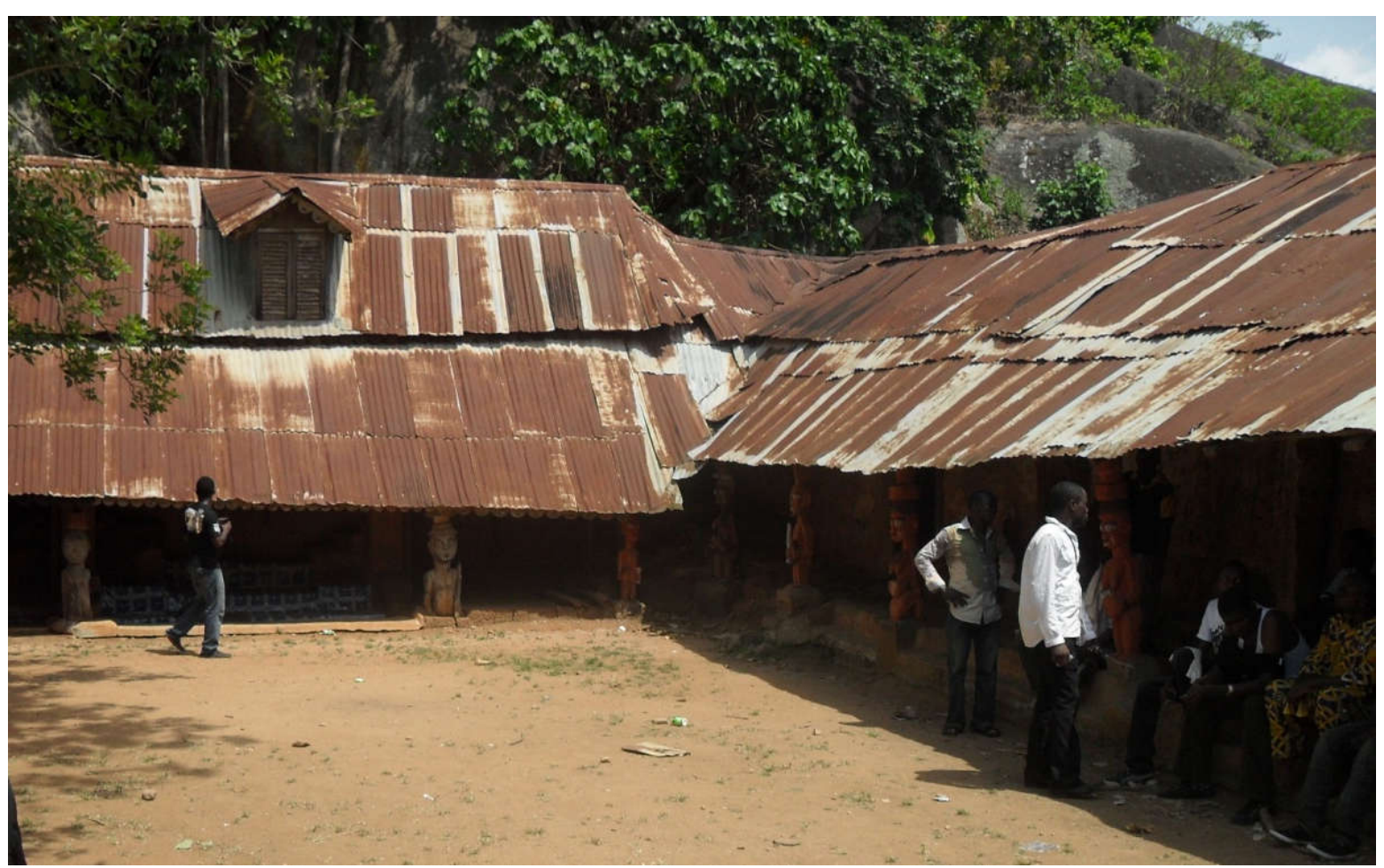

Figure 1. The ancient palace at the hilltop: Field Survey

\subsection{The Administrative Quarters}

At the top of Idanre, there were three administrative quarters headed by a quarter chief and six minor sub-quarters also headed by quarter heads. The five sub-quarters attached with one or the other principal quarters. The Palace (Aafin) is the home of the reigning Owa. He lives there with his household, wives (Oloris) and children and his several courtiers, servants called Alegwas. The Alegwas though restricted to the palace, to the service of the Owa and his household are also titled chiefs; but their title except for some few who are different from the general chieftaincy title.

\subsection{Orosun Sacred Groove and Festival}

Like many other parts of Oghoduwa (Oduduwa). land; the people of Idanree believe in ancestral worship. The people worship two principal spiritual ancestors OLOFIN and OROSUN. Olofin was the founder as well as the spiritual leader Of Idame, formerly called Ufeke and Orosun was Olofin's celebrated wife' and a mysterious' woman during her lifetime. Idanre history says she was the celebrated MOREMI of Ife who cane with Olofin to Ufeke and died at Idanre thus traditional religious worship in Idanre was built around these two personalities. The fifth month of the year is called osu Orosun, the month of Orosun festival, which is always celebrated in May, although there is record that Orosun festival had at times been celebrated in June many years back. It is however, now regularly celebrated in the month of May every year.

\subsection{Natural Resources}

Aghagha hill emits mist throughout the year and the Arun river is said to derive its source from the hot confines of the hill. Enigmatic Arun River is tucked at a corner of the hill. The water is colourless, odourless and the people drink from the sources for it is tasteless. People within outside the community fetch the water for spiritual cleansing and healing. Those who venture mid-stream claim that they experienced the presence of a supernatural being, an eerie feeling which makes the head swell. The experience is definitely not for the lily-livered 


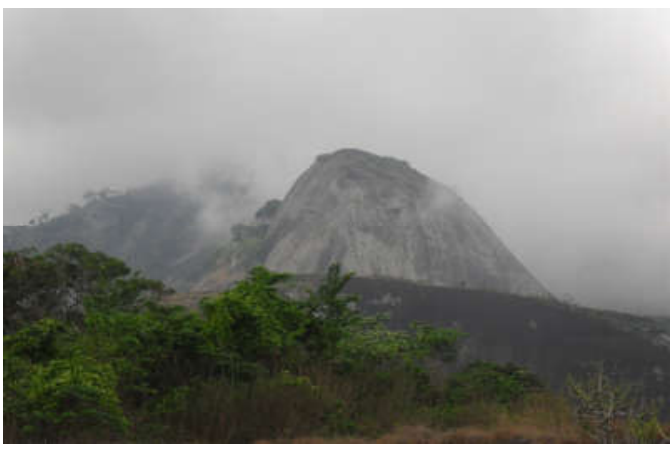

Figure 2. The Aghagha Hill Emitting Smoke: Field Survey

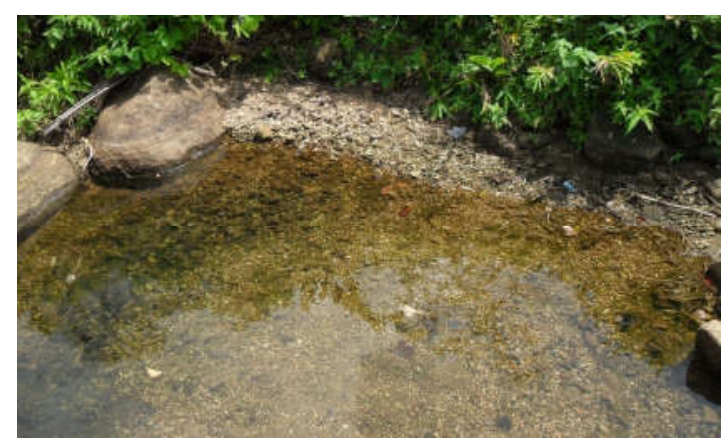

Figure 3. The Arum River: Field Survey

Flora and Fauna of the hills are also unique. There is special specie of tailless animal called Hyrax. Monkeys are also sported near Orosun hills. The hill also serves as home to a group of Bats and the people hold a unique festival of Bats every year. Idanre hills are blessed with twenty-five unique species of bats that are peculiar to the community which no other parts in Nigeria share with them not even in Africa. As a result of this uncommon blessing of fauna (bats) there is a harvest in acknowledgement of this great blessing by Mother Nature which is usually commemorated by all inhabitants of the community during the month of February called Osun Use for Adan (Bats) inside one of claves that shelter these bats.

\subsection{Existing Land Use and Settlement Pattern of Idanre Community}

Most of the land uses in the study area are residential and agricultural. The reason for these uses was not far fetch as the people of Idanre are largely operating agrarian economy. Their major farm products are cocoa (Theobram Cacao) which is cash crop and plantain (food crop). It should be noted the community and his neighboring town were among the largest cocoa producing communities in the western part of the country and Nigeria as a whole.

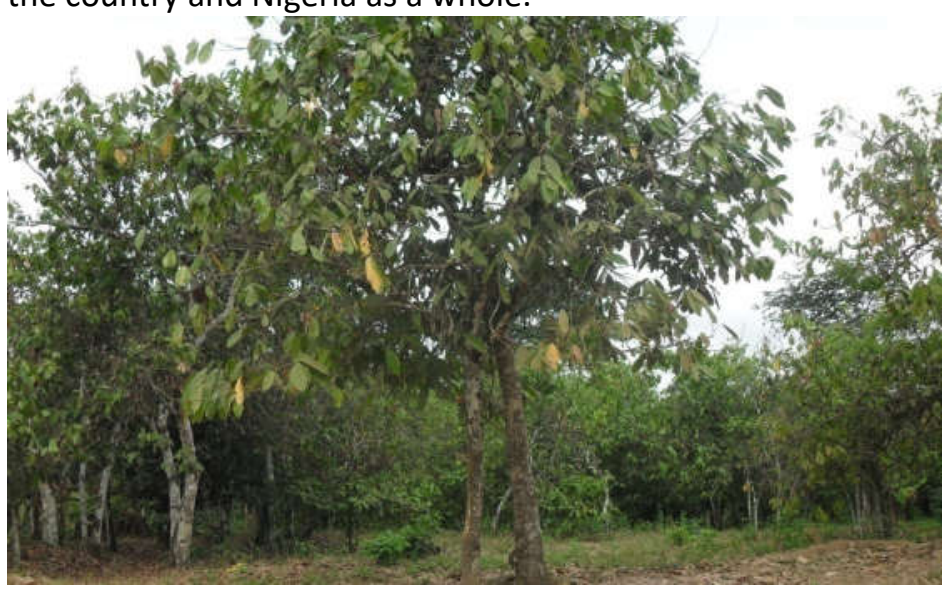

Figure 4. Cocoa farm: Field Survey

\subsection{Urban Culture in Creative Industry}

\section{Urban Culture in Creative Industry}

Innovation, creativity, flexibility, reflexivity, responsiveness characterized creative industries. Pursuit of cultural products and intellectual development is premised on the value of local culture to explore for the content, people and cities to meet the needs of economic development as the goal of a resourceconserving development and as such become cultural products accumulate wealth, create jobs and improve the competitiveness of the drivers of creative industries in face of COVID-19 pandemic. Today, cultural and creative industries in Idanre is becoming one of the largest industrial sectors, the volume of output and employment, second only to business services. Creative industries in Idanre is based mainly on the cultural sector in other to foster Idanre city prosperity. Idanre people posited that the nature and 
value of culture is to increase people's spiritual world and the ideological realm, and therefore the provision of cultural products is to identify the spiritual and cultural needs of consumers. Figure 5 is a synopsis of probable memorabilia products that can be derived from the precious heritage of Idanre.

\begin{tabular}{|c|c|c|c|c|}
\hline$S / N$ & Process & Material & End Product & Remark \\
\hline 1 & $\begin{array}{l}\text { Culture and force of } \\
\text { attraction combined } \\
\text { with cultural content }\end{array}$ & $\begin{array}{l}\text { Cultural Display, } \\
\begin{array}{l}\text { and } \\
\text { Pance } \\
\text { Performance, } \\
\text { Custom Show }\end{array}\end{array}$ & $\begin{array}{l}\text { Traditional folk song and } \\
\text { dance, wrestling competition, } \\
\text { hunting etc. }\end{array}$ & $\begin{array}{l}\text { Develop for } \\
\text { community } \\
\text { cultural arena }\end{array}$ \\
\hline 2 & $\begin{array}{l}\text { Concept of culture to } \\
\text { create new } \\
\text { products }\end{array}$ & $\begin{array}{l}\text { Combination of } \\
\text { culture and skills }\end{array}$ & $\begin{array}{l}\text { Musical instrument, arts and } \\
\text { crafts, sales of cultural } \\
\text { products like variety of bats, } \\
\text { cocoa products etc. }\end{array}$ & $\begin{array}{l}\text { Ideal for city } \\
\text { brand }\end{array}$ \\
\hline 3 & $\begin{array}{l}\text { Value of cultural } \\
\text { product viz a vis } \\
\text { creative industry }\end{array}$ & $\begin{array}{l}\text { Products to meet the } \\
\text { emotional needs }\end{array}$ & $\begin{array}{l}\text { Sacred places to appeal the } \\
\text { emotion of the people such } \\
\text { as the old palace on the hill } \\
\text { top, cultural relics include } \\
\text { Owa's Palace, shrines, old } \\
\text { Court, Belfry, Agbooogun's } \\
\text { footprint, thunder water (Omi } \\
\text { Aopara) and burial mounds } \\
\text { and grounds. }\end{array}$ & $\begin{array}{l}\text { Products-- for } \\
\text { Souvenirs }\end{array}$ \\
\hline 4 & $\begin{array}{l}\text { Promotion of } \begin{array}{r}\text { culture } \\
\text { for } \\
\text { development }\end{array} \\
\text { urban }\end{array}$ & $\begin{array}{l}\text { Cultural products } \\
\text { reflecting the image of } \\
\text { the city }\end{array}$ & $\begin{array}{l}\text { Logo reflecting the image of } \\
\text { the city depicting hills and } \\
\text { abundance of bats }\end{array}$ & $\begin{array}{l}\text { Ideal for urban } \\
\text { morphology } \\
\text { regeneration }\end{array}$ \\
\hline 5 & $\begin{array}{l}\text { Promotion of cultural } \\
\text { products to enhance } \\
\text { economic growth }\end{array}$ & $\begin{array}{l}\text { Product } \\
\text { Modelling, design, } \\
\text { packaging, } \\
\text { trademarks, } \\
\text { advertising }\end{array}$ & $\begin{array}{l}\text { Cliché and logo imprint or } \\
\text { engrave on household } \\
\text { common use such as T-shirt, } \\
\text { Face-cap, Mug, Cup, Face- } \\
\text { towel, Exercise books, Wood } \\
\text { carving and decorative arts. }\end{array}$ & $\begin{array}{l}\text { Model for city } \\
\text { imageability }\end{array}$ \\
\hline 6 & $\begin{array}{l}\text { Cultural product to } \\
\text { enhance } \\
\text { competitiveness of } \\
\text { cities }\end{array}$ & $\begin{array}{lr}\text { Unique } & \text { cultural } \\
\text { product in } & \text { any } \\
\text { dimensions } & \end{array}$ & $\begin{array}{l}\text { Unique scenic view, variety of } \\
\text { bats }\end{array}$ & $\begin{array}{l}\text { Packaged for } \\
\text { city } \\
\text { comparative } \\
\text { advantage }\end{array}$ \\
\hline
\end{tabular}

Figure 5. Urban culture in creative industry: Field Survey

The table above based upon the various responses from different groups revealed that there has been general shift in agrarian way to creative industries rooted in culture. This will have a large impact on the way of life, the use of land and the neighbourhoods in the city. In this respect to the new economy, the new strategies that have economic, social and spatial dimensions have to be developed for urban development. Artistic and technological creativity as the key driver of the new knowledge economy moved to the centre of contemporary urban policies. The new economic and social strategies relevant connecting creativity have a tremendous impact on the space, land use decisions for creating new spaces with the creative industries as culture when packaged (tourism) have a mutual effect on urban economy, social and quality of life and images of the cities. 


\section{Conclusion}

Community opinion, cultural custodians, traditional rulers, heritage tourists were various constituents of Idanre city system. The fundamental components of Idanre city were configured by urban space and the urban space memory which can be translated into urban prosperity for Idanre city.

This paper recommends that innovation capacity and citizenry interaction are fundamental for desired prosperity through a robust heritage resource deeply rooted in creative industry. Government need to promote the development of cultural heritage and creative industries. Again, the role of urban planning policies should be considered in favour of mixed-use, well defined and connected spatial clusters within the urban network. There are needs for good leadership, political stability, cooperation and integration among different authorities. An integrated and comprehensive strategy is also needed for the development of Idanre creative industries.

\section{References}

Adejumo, O. \& Esan, O., 2020. Urban Transformation: Reimagining The Soul of Nigerian Cities.. Lagos Journal of Architecture. Universi, Volume 4, pp. 107-118.

Adeleye, Y. B. A. \& Folarin, K., 2014. Appraisal of the Geotourism Potentials ofthe Idanre Hills, Nigeria. Geoheritage, pp. 193-203.

Akintan, A., 2008. The origin of Orosun festival: excerpts from Idanre history. Idanre: Afrografika Publishers.

Andres, L., 20111. Alternative Initiatives, Cultural Intermediaries and Urban Regeneration: The case of La Friche (Marseille). European Planning Studies, 19(5), pp. 795--811.

Antia, O., 2005. Akwa Ibom Cultural Heritage: Its Incursion by Western Culture and its Renaissance. Uyo: Abbny Publishers.

Antonio, L., 2013. What is Culture?. Merit Research Journal of Education and Review, 1(6), pp. 126-1132.

Comunian, R., 2011. Rethinking the creative city: the role of complexity, networks and interactions in the urban creative economy. Urban Study, Volume 48, p. 1157-1179.

Elseragy, A., Elnokaly, A. \& Sabbagh, M., 2017. Revitalizing Alexandria through its Symbolic Significance of Heritage, Urban Form, and the Distinctive Spirit of Place. s.l., Proceedings of the International Confer Conference on Changing Cities III Spatial, Design, Landscape and Socio-Economic Dimensions.

Eneji, M. A., Odey, F. A. \& Bullus, M. L., 2016. Diversification of Nigeria's Economy; Impact of Tourism on Sustainable Development in Nigeria. International Journal of Research in Humanities and Social Studies, pp. 36-44.

Espinoza, C. S., 2015. Narrativizing cities, localizing urban memories the (re)construction of place through urban Cueca in Santiago de Chile (1990-2010). Space and Culture, Volume 19, pp. 94-109.

Fajemirokun, B., 2004. Legal Mechanisms for the protection and promotion of cultural and Historical Heritage in Urban Areas, s.I.: A Paper Submitted at Symposium on the Protection and promotion of cultural and Historical Heritage in Urban Areas.

Flew, T., 2011. The Creative Industries, Culture and Policy. London: Sage.

Jennifer, M. \& Martin , A., 2018. How Urban Spaces Remember: Memory and Transformation at Two Expo Sites. Yokohama, ResearchGate, pp. 1-13. 
Letícia, L., 2011. The Protection of World Heritage Settlements and their Surroundings: Factors affecting Management Policy and Practice. s.l.:Thesis submitted to the Edinburgh College of Art in fulfilment of the requirements of the Degree of Doctor of Philosophy, University of Edinburgh.

Mark, J. S. \& Susan, C. S., 2008. From Creative Economy to Creative Society. Social Impact of the Arts Project, pp. 1-14.

Pietrobruno, S., 2009. Cultural Research and Intangible Heritage: Culture Unbound. Journal of Current Cultural Research, Volume 1, pp. 227-247.

Scott, A., 2006. Creative Cities: Conceptual Issues and Policy Questions. Journal of Urban Affairs, 28(1), pp. 1-17.

Shahrul, Y. S., Hasnizan, A. \& Elma, D. I., 2013. Heritage Conservation and Regeneration of Historic Areas in Malaysia. Procedia - Social and Behavioral Sciences, p. 105 ( 2013 ) 418-428.

Somekh, N., Correa, V. \& Mauro, C., 2017. The Soul of the city: Urban Memory and Heritage. Union Internationale des Architectes (UIA) Seoul World Architects Congress, pp. 1-6.

UNESCO-ICOMOS, 2019. Evaluations of Nominations of Cultural and Mixed Properties, s.l.: ICOMOS.

Yusuff, M. A. \& Akinde, M. A., 2015. Tourism Development and Economic Growth Nexus: Nigeria's Experience. European Journal of Hospitality and Tourism Research , pp. 1-9. 